\title{
PENGGUNAAN MODEL PEMBELAJARAN JIGSAW UNTUK MENINGKATKAN KEAKTIFAN DAN HASIL BELAJAR IPA PADA MATERI POKOK TEKANAN SISWA KELAS VIII B SEMESTER 2 MTS NU MIFTAHUL ULUM MARGASARI KABUPATEN TEGAL TAHUN PELAJARAN 2014 / 2015
}

\author{
Mohamad Muhazir \\ MTs NU Miftahul Ulum Margasari
}

Agus Sudarmanto

Fakultas Sains dan Teknologi UIN Walisongo

\begin{abstract}
Abstrak
Pembelajaran Ilmu IPA pada siswa MTs memberikan suatu tantangan yang besar bagi para pengajarnya. Hal itu disebabkan oleh sebagian besar materi Ilmu IPA terdiri dari dari konsep-konsep yang abstrak yang harus diajarkan. MTs NU Miftahul Ulum Margasari Kabupaten Tegal kelas VIII B, dalam kegiatan belajar mengajar maupun dalam penugasan siswa cenderung pasif dan menunggu temanya untuk mengerjakan tugas. Beberapa siswa bahkan sama sekali tidak mengerjakan tugas dan lebih memilih bercakap-cakap atau bermain-main dengan temannya. Dalam diskusi kelompok siswa cenderung diam, tidak aktif dan induvidualis, hal ini menunjukan aktivitas belajar masih rendah.

Dari keadaan di atas, maka peneliti tertarik untuk mengadakan penelitian tindakan kelas dengan menggunakan model pembelajaran jigsaw, peneliti berusaha untuk menerapkan efektifitas pembelajaran pada siswa. Peningkatan kualitas proses dapat diamati dari meningkatnya partisipasi dan motivasi siswa dalam proses pembelajaran, sedangkan kualitas hasil belajar dapat diketahui dari adanya peningkatan rerata hasil belajar. Adapaun pelaksanaannya terdiri dari : Pra-Siklus, Siklus I, dan Siklus II. Setiap siklus terdiri dari perencanaan, tindakan, pengumpulan data, dan refleksi.

Hasil dari penelitian ini adalah pada saat kondisi Pra-Siklus dengan metode konvensional, tingkat ketuntasan hasil belajar siswa $17 \%$ dengan nilai rata-rata 58, sedangkan untuk keaktifan $22 \%$. Setelah melaksanakan pembelajaran pada Siklus I dengan metode diskusi, tingkat ketuntasan hasil belajar siswa mengalami kenaikan yaitu menjadi $46 \%$ dengan nilai rata-rata 62, untuk keaktifan ketuntasan siswa $54 \%$.
\end{abstract}


Pada saat melaksanakan pembelajaran pada siklus II dengan metode jigsaw, di dapat hasil untuk tingkat persentase ketuntasan hasil belajar siswa $83 \%$, dengan ketuntasan keaktifan siswa $82 \%$ dan rata-rata hasil belajar siswa 80, hal ini membuktikan bahwa terjadi peningkatan yang signifikan dari hasil belajar siswa dan keaktifan siswa dari tahap Pra-Siklus, siklus I dan siklus II. Dan juga membuktikan bahwa penggunaan metode pembelajaran jigsaw pada mata pelajaran IPA materi Tekanan dapat meningkatkan keaktifan dan hasil belajar siswa kelas VIII B MTs NU Miftahul Ulum Margasari Kabupaten Tegal Tahun ajaran 2014 / 2015.

Kata kunci : tekanan, jigsaw, hasil belajar

\section{PENDAHULUAN}

Pembelajaran Ilmu IPA pada siswa MTs memberikan suatu tantangan yang besar bagi para pengajarnya. Hal itu disebabkan oleh sebagian besar materi Ilmu IPA terdiri dari dari konsep-konsep yang abstrak yang harus diajarkan dalam waktu yang relatif singkat. Keterbatasan waktu juga menyebabkan pembelajaran beberapa konsep ilmu IPA mengacu pada transfer pengetahuan untuk mengejar target kurikulum. Selain itu sebagian besar guru pada prakteknya masih mengajar menggunakan metode ceramah.

MTs NU Miftahul Ulum Margasari merupakan sekolah yang berada di Desa Karangjati Kecamatan Margasari Kabupaten Tegal. Sebagai sekolah non favorit, sebagian besar siswa yang masuk ke MTs ini merupakan limpahan dari sekolahsekolah yang lebih favorit.

Dalam kegiatan belajar mengajar maupun dalam penugasan IPA siswa cenderung pasif dan menunggu temanya untuk mengerjakan tugas. Beberapa siswa bahkan sama sekali tidak mengerjakan tugas dengan alasan tidak bisa atau tidak membawa buku dan lebih memilih bercakap-cakap atau bermain-main dengan temanya dari pada mengerjakan tugas. Dalam diskusi kelompok siswa cenderung diam, tidak aktif dan individualis, hal ini menunjukan aktivitas belajar masih rendah. 
Berdasarkan latar belakang di atas, peneliti tertarik untuk melakukan penelitian dengan judul yaitu : “Penggunaan Model Pembelajaran Jigsaw Untuk Meningkatkan Aktifitas dan Hasil Belajar IPA pada Materi Pokok Tekanan Siswa kelas VIII B Semester 2 MTs NU Miftahul Ulum Margasari Kabupaten Tegal Tahun Pelajaran 2014/2015".

\section{METODE PENELITIAN}

Jenis penelitian ini merupakan suatu Penelitian Tindakan Kelas (PTK). Penelitian ini dilakukan pada Siswa Kelas VIII B Semester 2 MTs NU Miftahul Ulum Margasari Kabupaten Tegal Tahun Pelajaran 2014 / 2015" yang dilaksanakan selama 2 bulan pada awal semester 2 mulai 5 Januari sampai 31 Pebruari 2015.

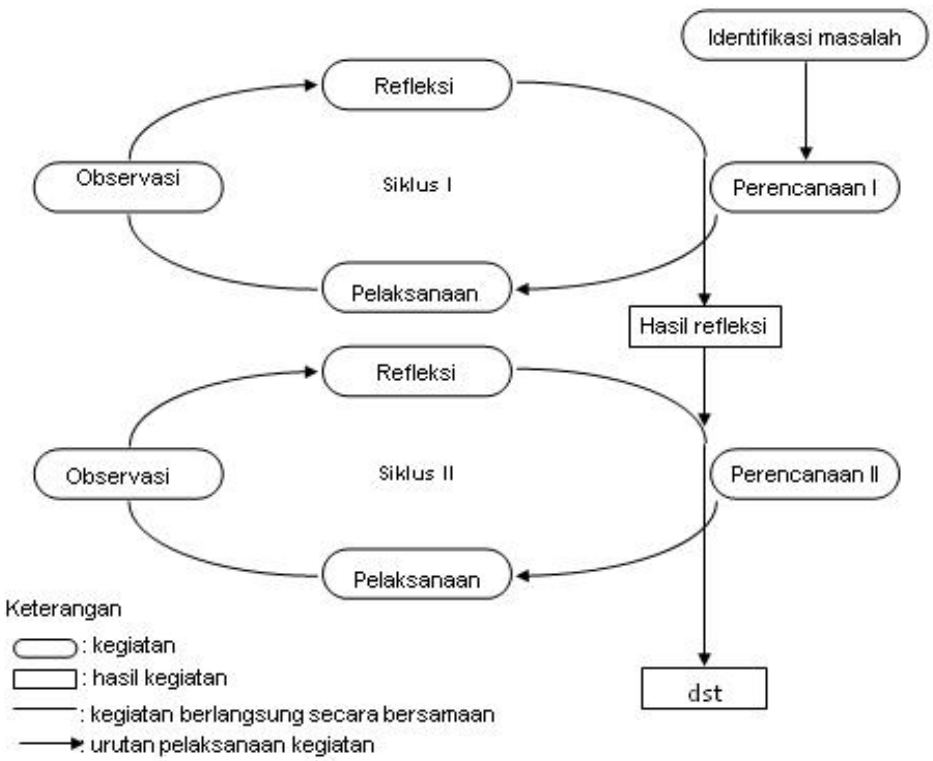

Gambar 3.1 Rancangan Siklus Penelitian. 
Adapun metode yang digunakan peneliti dalam teknik pengumpulan data adalah sebagai berikut:

\section{Metode Tes atau Uji kompetensi.}

Tes ini diberikan pada semua siswa pada akhir siklus. Tes digunakan untuk mengetahui kemampuan hasil belajar siswa.

\section{Metode Observasi.}

Observasi digunakan untuk mengamati keaktifan siswa kelas VIII B di MTs NU Miftahul Ulum Margasari.

Penilaian karakter percaya diri siswa dilaksanakan pada saat proses pembelajaran mulai dari kegiatan apersepsi, eksplorasi, elaborasi, konfirmasi dan penutup.

\section{Metode Dokumentasi.}

Dokumentasi dalam penelitian ini digunakan untuk memperoleh data mengenai nama-nama peserta didik kelas VIII B MTs NU Miftahul Ulum Margasari tahun ajaran 2014/2015.

Teknik analisis data pada penelitian ini menggunakan teknik analisis deskriptif kualitatif, yaitu suatu metode penelitian yang bersifat menggambarkan sesuai dengan kenyataan dengan data yang di peroleh di lapangan.

Untuk menganalisis tingkat keberhasilan atau persentase keberhasilan siswa setelah proses belajar mengajar setiap putaran baik Pra-Siklus, Siklus I, dan Siklus II. Untuk menganalisi tingkat keberhasilan hasil belajar siswa peneliti akan memberikan evaluasi berupa soal-soal tes tertulis pada akhir siklus. Untuk mencari nilai rata-rata tes formatif hasil belajar siswa dapat rumuskan :

$$
\bar{X}=\frac{\sum N}{\sum S}
$$


Keterangan :

$\bar{X} \quad=$ Nilai Rata-rata tes formatif.

$\Sigma \quad N=$ Jumlah Semua Nilai Siswa.

$\Sigma \quad S \quad=$ jumlah Siswa.

Adapun cara menghitung persentase ketuntasan belajar siswa dapat digunakan rumus sebagai berikut :

$$
P=\frac{\Sigma T}{\Sigma S} \times 100 \%
$$

Keterangan :

$P \quad=$ Persentase Ketuntasan Siswa.

$\Sigma T=$ Jumlah Siswa yang tuntas Belajar.

$\Sigma \quad S=$ Jumlah Siswa.

Dari keterangan di atas maka di MTs NU Mifatahul Ulum Margasari menggunakan standar untuk KKM (ketuntasan kelas maksimum) IPA kelas V III sebesar 70 .

\section{HASIL PENELITIAN DAN PEMBAHASAN}

\section{Prasiklus}

Pada kegiatan Pra-Siklus, peneliti melakukan kegiatan secara konvensional pada mata pelajaran Ilmu Pengetahuan Alam (IPA) materi Gaya. Berikut ini adalah hasil penelitian yang penulis lakukan berdasarkan hasil belajar siswa pada nilai tes kompetensi adalah :

\begin{tabular}{|l|c|c|c|c|}
\hline No & Siklus & $\begin{array}{c}\text { Rata-rata } \\
\text { hasil belajar }\end{array}$ & $\begin{array}{c}\text { Persentase ketuntasan } \\
\text { hasil belajar }(\%)\end{array}$ & $\begin{array}{c}\text { Persentse keaktifan } \\
\text { siswa }\end{array}$ \\
\hline 1 & Pra-Siklus & 58 & $17 \%$ & $22 \%$ \\
\hline
\end{tabular}


Pada kondisi Pra-siklus menunjukan bahwa dari 35 siswa kelas VIII B, pada waktu mengikuti kegiatan belajar mengajar (KBM) pembelajaran IPA dengan materi Gaya dengan metode konvensional hanya ada 8 siswa yang aktif dan 27 siswa tidak aktif, dengan persentase keaktifan siswa hanay $22 \%$ hal ini dapat dibuktikan dari dari tabel hasil belajar di atas, diperoleh data bahwa tingkat rata-rata hasil belajar siswa kelas VIII B pada mata pelajaran IPA materi Gaya tahap pra-siklus adalah 58 sedangkan tingkat persentase ketuntasan hasil belajar siswa pada pra-siklus yaitu hanya $17 \%$ saja. Dengan melihat data di atas dan berdasarkan catatan kolaborator saat pembelajaran pada Pra-Siklus, maka peneliti dengan kolaborator melakukan refleksi. Hasil refleksi Pra-Siklus, belum memberikan hasil yang di harapkan masih ada siswa yang mendapatkan nilai di bawah KKM, dengan demikian melalui metode pembelajaran konvensional belum bisa untuk meningkatkan keaktifan siswa dalam belajar dan hasil belajar IPA pada materi Gaya. Dari hasil refleksi di atas pada pra siklus menunjukkan hasil yang kurang maksimal, maka penelitian akan di lanjutkan pada Siklus 1.

\section{Siklus I}

Pada tahap Siklus I peneliti menggunakan metode pembelajaran dengan diskusi materi Energi yang di bagi dalam 6 kelompok dimana masing-masing kelompok terdiri dari 5 sampai 6 orang. Tiap kelompok akan mendiskusikan pada materi yang telah di berikan oleh peneliti, kemudian hasil dari diskusi kelompok akan dipersentasikan di depan kelas secara bergantian. Berdasarkan hasil nilai tes Kompetensi siswa pada mata pelajaran IImu Pengetahuan Alam (IPA) pada materi Energi. Berikut ini adalah hasil penelitian yang penulis lakukan berdasarkan hasil belajar siswa pada nilai tes kompetensi adalah :

\begin{tabular}{|l|l|c|c|c|}
\hline No & Siklus & $\begin{array}{c}\text { Rata-rata hasil } \\
\text { belajar }\end{array}$ & $\begin{array}{c}\text { Persentase } \\
\text { ketuntasan hasil } \\
\text { belajar ( \%) }\end{array}$ & $\begin{array}{c}\text { Persentase } \\
\text { keaktifan } \\
\text { siswa }\end{array}$ \\
\hline
\end{tabular}




\begin{tabular}{|l|l|l|l|l|}
\hline 1 & Siklus I & 62 & $46 \%$ & $54 \%$ \\
\hline
\end{tabular}

Dari tabel di atas, diperoleh data bahwa tingkat rata-rata dan persentase ketuntasan hasil belajar siswa kelas VIII B pada Mata Pelajaran IPA materi Energi di Siklus I mengalami kenaikan dibandingkan tingkat rata-rata pada hasil belajar siswa pada tahap Pra-Siklus. Rata-rata hasil belajar siswa pada Siklus I menjadi 62 atau $54 \%$ sedangkan ketuntasan hasil belajar siswa pada Siklus I menjadi $46 \%$. Hasil refleksi Siklus I, belum memberikan hasil yang di harapkan nilai masih di bawah KKM, maka penelitian perlu di lanjutkan pada Siklus II.

\section{Siklus II}

Dalam pelaksanaan pembelajaran pada Siklus II ini, peneliti mengunakan model pembelajaran jigsaw. Dengan perubahan pembelajaran yang dilakukan pada Siklus II ini ternyata mengalami peningkatan yang lebih baik. Hal ini ditunjukan melalui tes kompetensi di bawah ini:

\begin{tabular}{|l|l|c|c|c|}
\hline No & Siklus & $\begin{array}{c}\text { Rata-rata hasil } \\
\text { belajar }\end{array}$ & $\begin{array}{c}\text { Persentase } \\
\text { ketuntasan hasil } \\
\text { belajar(\%) }\end{array}$ & $\begin{array}{c}\text { Persentase } \\
\text { keaktifan } \\
\text { siswa }\end{array}$ \\
\hline 1 & Siklus II & 80 & $83 \%$ & $82 \%$ \\
\hline
\end{tabular}

Dari tabel Siklus II di atas, diperoleh data bahwa tingkat rata-rata dan persentase ketuntasan hasil belajar siswa kelas VIII B pada mapel IPA materi Tekanan pada Siklus II mengalami kenaikan. Untuk nilai rata-rata hasil belajar siswa pada Siklus II menjadi 80. Untuk tingkat persentase ketuntasan hasil belajar siswa pada Siklus II meningkat menjadi $83 \%$.

Dari keseluruhan data mengenai hasil belajar siswa mulai dari Pra-siklus, Siklus I, Siklus II, ada peningkatan hasil belajar siswa dan aktifitasnya pada tiap siklusnya. 


\section{KESIMPULAN}

Dari penelitian yang dilakukan diatas, dapat disimpulkan bahwa : hasil belajar dan keaktifan siswa pada tiap siklusnya mengalami penigkatan dengan divariasinya metode pembelajarannya, sehingga Penggunaan model pembelajaran jigsaw dapat meningkatkan hasil belajar dan keaktifan IPA materi Tekanan pada siswa kelas VIII B semester 2 MTs NU Miftahul Ulum Margasari Tahun ajaran 2014/2015.

\section{DAFTAR KEPUSTAKAAN}

Anas Sudijono, "Pengantar Statistik Pendidikan", Jakarta: Rajawali Pers, 2011. Dimyati, Mudjiono, "Belajar dan Pembelajaran", Jakarta: Rineka Cipta, 1999.

Eduard Nurpatria, "Seri Buku soal Super IPATerpadu untuk MTs/SMP Kelas VIII", Jakarta: Erlangga, 2009.

Fadhly, "Model pembelajaran Kooperatif Tipe Jigsaw", TK-FPTt.

Hisyam Zaini, dkk.,"Strategi Pembelajaran Aktif", cetakan ke-6, Yogyakarta: CTSD Institut Agama Islam negeri Sunan Kalijaga, 2007.

M.Ngalim Purwanto, "Prinsip-prinsip dan teknik evaluasi", Bandung: Rosda Karya 2002.

Oemar Hamalik, "Kurikulum dan pembelajaran”, Jakarta: Bumi aksara, 2001.

Sugiono, "Metode Penelitian Pendidikan: Pendekatan Kuantitatif, kualitatif, dan R\&D”, Bandung: Alfabeta, 2010.

Saeful Karim, Ida Kaniawati, Yuli Nurul Fauziah, Wahyu Sopandi, "Buku Paket IPA Untuk MTS/SMP Kelas VIII Belajar IPA", Panduan Belajar IPA Terpadu Di terbitkan oleh pusat perbukuan Departemen Pendidikan Nasional, 2008 (BSE).

Suharsimi Arikunto, "Penelitian Tindakan Kelas", Jakarta: Bumi Aksara, 2008.

Sardiman A.M, "Interaksi dan Motivasi Belajar", Jakarta: Raja Grafindo Persada, 1994.

Slameto, "Belajar dan Faktor-faktor yang mempengaruhi", Jakarta: Rineka Cipta, 2003.

Sugiyanto, "Model-model Pembelajaran inovatif", Surakarta: Yuma Pustaka, 2010.

Winasanjaya, "Kurikulum dan Pembelajaran", Teori dan Praktik pengembangan Kurikulum KTSP, Jakarta: Kencana, 2010.

Zaenal Arifin, "Evaluasi Instruksional”, Bandung: Remaja Rosdakarya, 1999. 